\title{
RE-INVENTING GINI RASIO DATA PENGELUARAN (KONSUMSI): KETIMPANGAN HARGA (GINI BIAS) ATAU KETIMPANGAN KESEJAHTERAAN (GINI RIIL)
}

\author{
Studi Kasus: Gini Rasio Jawa Timur 2015-2019 \\ (RE-INVENTING GINI EXPENDITURE DATA RATIO (CONSUMPTION): \\ PRICE INEQUALITY (GINI BIAS) OR WELFARE INEQUALITY (GINI REAL))
}

\author{
Hermanto $^{1}$, Dyah Pembayun Indrijatmiko \\ Kasi Statistik Kesra Bidang Statistik Sosial, Badan Pusat Statistik Provinsi Jawa Timur ${ }^{1}$ \\ Fungsional Statistisi Muda Bidang Statistik Produksi, Badan Pusat Statistik Provinsi Jawa Timur ${ }^{2}$ \\ E-mail: her@bps.go.id dan pembayun@bps.go.id
}

\begin{abstract}
ABSTRAK
Indeks gini merupakan salah satu sasaran pokok kinerja kabinet Presiden Jokowi, dalam RPJMN 20152019 dan RPJMN 2020-2024. Untuk memenuhi hal tersebut, indeks gini dari data pengeluaran bersumber dari data Susenas. Sebagai negara kepulauan, faktor luas dan hambatan geografis Indonesia menjadi salah satu kendala distribusi pasokan kebutuhan masyarakat. Ini berdampak pada besaran rupiah yang sama belum tentu dapat dibelanjakan dengan jumlah komoditi tertentu yang sama pula antar wilayah. Sehingga memungkinkan terjadinya kondisi semu, dimana tingkat pengeluaran yang lebih tinggi memiliki daya beli yang relatif sama. Kondisi ini berpotensi hasil indeks gini dari data pengeluaran memberikan hasil bias, terutama yang disebabkan oleh disparitas harga sebagai trade off luas dari hambatan geografis. Untuk menjawab masalah ini, dalam kajian ini dilakukan konversi data pengeluaran (konsumsi) Susenas ke paket konversi sekelompok komoditi kebutuhan dasar dalam garis kemiskinan di masing-masing wilayah. Hasil yang diperoleh dari kajian ini adalah perlu kehati-hatian dalam menafsirkan hasil indeks gini dari data pengeluaran (konsumsi) untuk melihat ketimpangan kesejahteraan masyarakat. Dengan menggunakan data Jawa Timur 2015-2019, menunjukkan bahwa ada faktor deviasi harga sebagai akibat penggunaan data konsumsi. Hasil indeks gini dari data pengeluaran (konsumsi) lebih tinggi dibanding indeks gini yang dihitung dari data konversi pengeluaran. Hal ini menunjukkan tingkat ketimpangan yang terjadi sebenarnya masih lebih rendah. Koefisien bias gini yang dihasilkan dalam kajian ini, dapat digunakan untuk melihat anomali yang terjadi dalam penghitungan gini dengan dua data di atas.
\end{abstract}

Kata kunci: Gini Rasio, Garis Kemiskinan, Kurva Lorenz, Koefisien Bias Gini

\section{ABSTRACT}

The Gini Index is one of the main performance targets of President Jokowi's cabinet, in the 2015-2019 RPJMN and 2020-2024 RPJMN. To fulfill this, the Gini index of expenditure data is sourced from Susenas. As an archipelagic country, the breadth and geographical constraints of Indonesia are one of the obstacles to the distribution of supply to the needs of the community. This has an impact on the same amount of rupiah, it is not certain that it can be spent on the same amount of certain commodities between regions. That is possible to have a pseudo-condition where a higher level of expenditure has relatively the same purchasing power. This condition has the potential for the Gini index results from the expenditure data to produce biased results, especially due to price disparities as a broad trade off of geographic barriers. To answer this problem, in this study, the Susenas expenditure (consumption) data conversion is carried out into a conversion package for a group of basic needs commodities in the poverty line in each region. The results obtained from this study are that caution is needed in interpreting the results of the Gini index from expenditure (consumption) data, to see the imbalance in people's welfare. Using East Java data for 20152019, shows that there is a price deviation factor as a result of using consumption data. The Gini index results from the expenditure (consumption) data are higher than the Gini index calculated from the expenditure conversion data. This shows that the level of inequality that occurs is actually still lower. The Gini bias coefficient produced in this study can be used to see the anomalies that occur in Gini calculations using the two data above. 


\section{PENDAHULUAN}

Indeks gini menjadi salah satu sasaran pokok kinerja kabinet Presiden Jokowi, tertuang dalam RPJMN 2015-2019 (RI, 2015) dan RPJMN 2020-2024 (RI, 2020) sebagai visi dari pemerataan pembangunan nasional. Untuk memenuhi indikator indeks gini tersebut data indeks gini BPS menjadi rujukannya. Data pengeluaran dari kegiatan Survei Sosial Ekonomi Nasional (Susenas) sebagai proxy dari data pendapatan rumah tangga digunakan sebagai data dasar dalam menghitung indeks gini. Data pengeluaran digunakan sebagai proxy, sesuai rekomendasi United Nations pada negara-negara yang pencatatan keuangannya masih rendah dalam survei rumah tangga (ILO, 2003). Adapun data pengeluaran yang digunakan dalam Susenas selama ini mencatat konsumsi makanan dan bukan makanan pada rumah tangga. Sebagaimana kita ketahui bersama bahwa Indonesia sebagai negara kepulauan (16.056 pulau) faktor luasnya (daratan mencapai sekitar 2,012 juta km2 dan laut sekitar 5,8 juta km2) dan hambatan geografis (laut Indonesia 2,5 kali lipat dari wilayah daratan) menjadi salah satu kendala distribusi pasokan kebutuhan masyarakat. Ini memberi dampak pada besaran rupiah yang sama, belum tentu dapat dibelanjakan dengan jumlah komoditi tertentu yang sama antar wilayah di Indonesia. Sehingga memungkinkan terjadinya kondisi semu, dimana tingkat pengeluaran yang lebih tinggi memiliki daya beli yang relatif sama. Atau dengan kata lain bervariasinya rupiah yang mesti dikeluarkan pada level utility yang sama untuk sekelompok komoditi sejenis yang dapat dikonsumsi. Kondisi ini tentu berpotensi hasil indeks gini dari data pengeluaran memberikan hasil bias, terutama yang disebabkan oleh disparitas harga sebagai trade off luas dari hambatan geografis. Potensi bias ini akan terjadi jika menggunakan hasil data pengeluaran Susenas secara langsung seperti berlaku selama ini. Bias terutama karena indeks gini digunakan untuk melihat kondisi ketimpangan kesejahteraan di masyarakat. Untuk itu maka perlu dilakukan upaya mengurangi dampak bias disparitas terutama harga pada data pengeluaran Susenas, sebelum dilakukan penghitungan indeks gini, minimal gambaran indeks gini yang komprehensif dengan melihat aspek bias tersebut. Dengan demikian diperoleh hasil indeks gini yang menggambarkan kondisi ketimpangan kesejahteraan di masyarakat sebenarnya.

Untuk mengukur ketimpangan dari distribusi pendapatan, menurut Debraj Ray (1998), terdapat empat prinsip; prinsip anonimitas (tidak peduli siapa yang mendapatkan penghasilan), prinsip kependudukan (ukuran populasi tidak menjadi masalah, hanya proporsi populasinya yang memperoleh tingkat pendapatan yang berbeda), prinsip pendapatan relatif (hanya pendapatan relatif yang penting, bukan pendapatan absolut), dan prinsip Dalton (jika satu distribusi pendapatan dapat dicapai dari yang lain dengan membangun urutan transfer regresif, lalu yang pertama distribusi harus dianggap lebih tidak setara daripada yang terakhir). Empat prinsip tersebut dapat digambarkan dalam Kurva Lorenz, yaitu grafis umum untuk menggambarkan tingkat pendapatan ketidaksetaraan di suatu negara (lihat Gambar 1). Kurva ini menunjukkan hubungan antara persentase penerima pendapatan dan persentase pendapatan yang diterima.

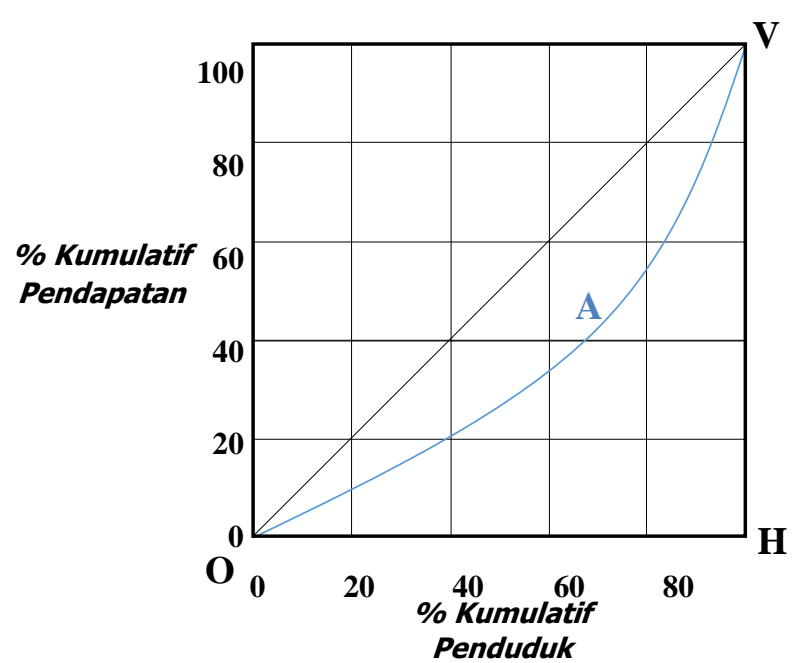

Gambar 56. Kurva Lorenz dari Distribusi Pendapatan 
Salah satu ukuran yang memenuhi semua empat prinsip dan konsisten dengan Kurva Lorenz adalah Koefisien Gini biasa juga disebut Gini Rasio atau Indeks Gini (Todaro:1988). Gini Rasio banyak diterapkan secara empiris. Termasuk jika menggunakan data pengeluaran sebagai proxy pendapatan dengan distribusi uniform (penduduk). Secara formulasi Gini Rasio dapat dituliskan sebagai berikut (BPS dan World Bank Institute, 2002):

Gini Rasio $(G R)=1-\sum_{i=1}^{n}\left(x_{i}-x_{i-1}\right)\left(y_{i}-y_{i+1}\right)$.

dimana:

$y=$ persentase kumulatif pengeluaran perkapita sebulan atau $\mathrm{f}(\mathrm{k})$

$x=$ persentase kumulatif penduduk

$i=1,2, \ldots . n$

Dengan menggunakan data pengeluaran dari konsumsi rumah tangga, dapat digunakan untuk mengukur kesejahteraan rumah tangga dari kondisi miskin atau tidaknya. Untuk itu diperlukan sebuah garis batas yang membedakan kondisi miskin tersebut (BPS dan World Bank Institute, 2002). Garis ini disebut Garis Kemiskinan (GK) atau sering dinotasikan z, merupakan tingkat pengeluaran minimum yang diperlukan untuk mencapai tingkat ulitilitas minimum atau tingkat pengeluaran untuk dapat memenuhi kebutuhan dasar (basic needs approach), baik konsumsi makanan maupun bukan makanan untuk setiap individu. Garis kemiskinan sendiri diperoleh dengan menentukan sekelompok komoditi konsumsi pangan dan non pangan (consumption bundle) yang cukup untuk kebutuhan konsumsi dasar, selanjutnya diperhitungkan biaya dari kebutuhan dasar tersebut. Untuk itu, garis kemiskinan dapat diformulasikan (Ravailion, 1998):

$$
z=e\left(p, x, u_{z}\right)
$$

Sehingga Garis Kemiskinan merupakan fungsi pengeluaran konsumen $e\left(p, x, u_{z}\right)$ yang merupakan biaya minimum untuk sebuah rumah tangga dengan karakteristik $\mathrm{x}$ dari suatu tingkat utilitas $\mathrm{u}$ (miskin) dengan harga $\mathrm{p}$.

\section{METODE}

Penghitungan gini, sejak tahun 2009 Indonesia menggunakan data pengeluaran individu (Kuncoro, 2010). Data pengeluaran yang digunakan bersumber dari data Susenas. Pemanfaatan lain menggunakan sumber data Susenas adalah data kemiskinan makro baik nasional, provinsi maupun kabupaten/kota. Metode penghitungan kemiskinan makro di Indonesia menggunakan headcount index untuk mendapatkan proporsi penduduk di bawah garis kemiskinan.

Meskipun keranjang yang digunakan sama, namun diperoleh variasi besaran GK antar waktu dan antar wilayah. Perbedaan ini terutama disebabkan terjadinya deviasi harga. Meskipun secara besaran rupiah berbeda-beda, GK ini merupakan satu unit yang sama, yaitu satu unit kebutuhan dasar minimum per orang per bulan. Sehingga jika pengeluaran perkapita pada data Susenas dibagi dengan GK yang berlaku di setiap wilayah pada periode waktu yang sama, akan diperoleh formulasi seperti di bawah ini:

$$
u_{i}=\frac{k_{i j}}{z_{j}}
$$

dimana:

$u=$ konversi pengeluaran riil (unit paket kebutuhan dasar minimum)

$k=$ pengeluaran perkapita sebulan

$z=$ garis kemiskinan

$j=1,2, \ldots . \mathrm{m}$ (m=wilayah)

Sehingga nilai pengeluaran rupiah perkapita sebulan $\left(k_{i}\right)$ menjadi konversi pengeluaran riil $\left(u_{i}\right)$ atau banyaknya unit paket kebutuhan dasar minimum yang bisa diperoleh setiap individu. Maka konversi pengeluaran riil ini dapat digunakan untuk melihat kondisi riil dari kemampuan daya beli individu-individu antar wilayah. Wilayah dengan tingkat harga tinggi maka nilai rupiah yang dikeluarkan juga lebih besar, begitu pula sebaliknya. Maka melihat ketimpangan dengan 
menggunakan data konversi ini dapat menjelaskan tingkat ketimpangan kesejahteraan yang sesungguhnya. Sehingga dari Persamaan 3 disesuaikan ke Persamaan 1, diperoleh:

$$
\text { Gini Rasio }_{w}(G R w)=1-\sum_{i=1}^{n}\left(x_{i}-x_{i-1}\right)\left(w_{i}-w_{i+1}\right) \text {. }
$$

dimana:

$w=$ persentase kumulatif konversi pengeluaran riil (unit paket kebutuhan dasar minimum) atau $\mathrm{f}(\mathrm{u})$

$\mathrm{i}=1,2, \ldots . \mathrm{n}$

Hasil yang diperoleh menggunakan Persamaan 4, merupakan indeks Gini yang lebih riil dalam menjelaskan ketimpangan kesejahteraan. Adapun perbedaan hasil antara Gini pada Persamaan 1 dan Persamaan 4, tidak akan terjadi jika variasi GK antar wilayah relatif sama, $z=z_{1}=z_{2}=$ $\cdots=z_{m}$, karena andil besaran persentase kumulatif $y_{i}=w_{i}$.

Dari perbandingan hasil antara Persamaan 1 dan Persamaan 4, atau perbandingan antara $G R$ dan $G R w$, hasil dari kajian ini diperkenalkan sebuah nilai berupa koefisien bias gini $(K B G)$ dari data pengeluaran/konsumsi, dengan formulasi:

$$
K B G=\frac{(G R-G R w)}{G R w}
$$

Sebagai ilustrasi (lihat Gambar 2), misalkan kurva warna biru mewakili hasil gini dari pengeluaran (GR) atau perbandingan luasan antara $O A V / O H V$. Untuk kurva warna hijau (perbandingan luasan kurva $\mathrm{OCV} / \mathrm{OHV}$ ) dan merah (perbandingan luasan kurva $\mathrm{OBV} / \mathrm{OHV}$ ) mewakili dua kemungkinan hasil dari gini konversi pengeluaran riil $\left(G R_{w}\right)$.

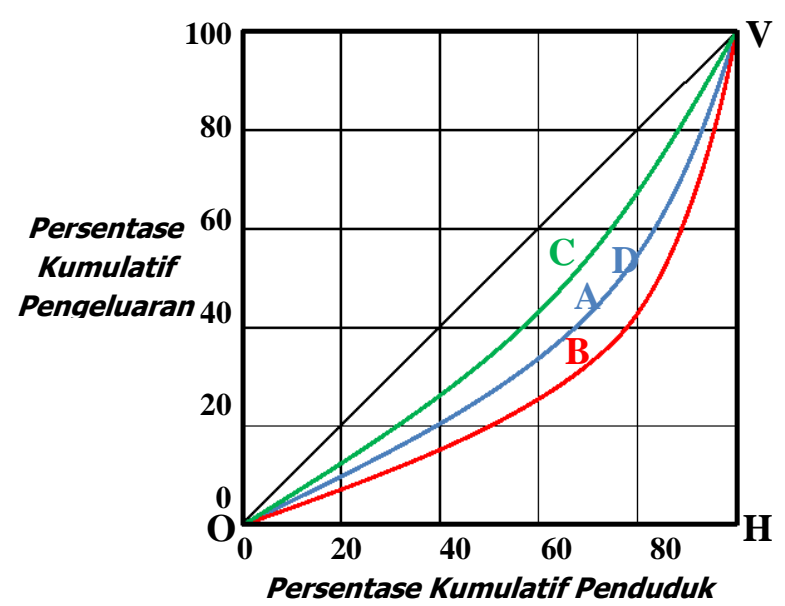

Gambar 2. Kurva Lorenz Data Pengeluaran Konsumsi Perkapita dan Konsumsi Perkapita Riil

Berdasarkan kondisinya, $K B G$ dapat bernilai 0 , jika tidak terjadi deviasi harga antara wilayah $\left(z=z_{1}=z_{2}=\cdots=z_{m}\right)$ atau $G R=G R w$ dapat diilustrasikan dengan perbandingan kurva OAV terhadap $O D V$. KBG bernilai positif, dapat diilustrasikan dengan perbandingan kurva $O A V$ terhadap $O C V$, berarti hasil ketimpangan GR pengeluaran salah satunya disebabkan oleh deviasi harga antar wilayah. Pada kondisi ini, sebenarnya ketimpangan riil $\left(G R_{w}\right)$ kesejahteraan lebih rendah. Sementara itu, jika nilai KBG bernilai negatif atau diilustrasikan perbandingan kurva OAV terhadap kurva $O B V$, maka indeks gini pengeluaran yang dihasilkan justru lebih rendah dari ketimpangan kesejahteraan yang sebenarnya/riil $\left(G R_{w}\right)$. Atau tingkat ketimpangan kesejahteraan riilnya lebih tinggi.

Sebagai bahan kajian empiris, untuk melihat kondisi di atas digunakan data Susenas Maret Provinsi Jawa Timur. Pertimbangan kajian di Provinsi Jawa Timur, terutama karena luasnya cakupan wilayah yang terdiri atas 38 kabupaten/kota dan menjadi provinsi dengan jumlah kabupaten/kota terbanyak. Selain itu, ada potensi hambatan struktural karena empat kabupaten di Jawa Timur terpisah daratan dengan 34 kabupaten/kota yang lain, karena berada di Pulau Madura. Kondisi ini cukup relevan dengan potret Indonesia. Untuk data garis kemiskinan, diperoleh dari publikasi "Data dan Informasi Kemiskinan Kabupaten/Kota" yang dipublikasikan 
BPS setiap tahun sampai level kabupaten/kota. Untuk tahun penelitian menggunakan rentang tahun 2015-2019, merujuk pada data Susenas periode Maret.

\section{HASIL DAN PEMBAHASAN}

Berdasarkan gambaran deskriptif dari Tabel 1, rata-rata rupiah pengeluaran perkapita di Jawa Timur dalam rentang 2015-2019 mengalami peningkatan setiap tahunnya. Namun secara rill nilai rupiah tersebut jika di konversi dalam unit paket kebutuhan dasar, rata-rata unitnya berfluktuatif selama 2015-2019. Rata-rata unit yang diperoleh di tahun 2016 dan 2019 lebih rendah dibandingkan tahun sebelumnya. Sementara itu, baik untuk nilai rupiah pengeluaran perkapita maupun konversi dalam unit paket kebutuhan dasar, nilai standar deviasi, nilai minimum, dan nilai maksimum memiliki kecenderungan peningkatan selama 2015-2019. Dari perbandingan nilai maksimum terhadap nilai minimum, nilai yang diperoleh dari data rupiah pengeluaran perkapita selalu lebih tinggi dibandingkan konversi pengeluaran dalam unit paket kebutuhan dasar untuk setiap tahunnya. Demikian pula untuk coefficient of variation, nilai yang diperoleh dari data rupiah pengeluaran perkapita juga selalu lebih tinggi dibandingkan konversi pengeluaran dalam unit paket kebutuhan dasar selama 2015-2019. Ini berarti secara acak, data yang diperoleh dari konversi pengeluaran dalam unit paket kebutuhan dasar akan memiliki variasi lebih kecil terhadap nilai rata-ratanya.

Tabel 38. Statistik Deskriptif Pengeluaran Perkapita dan Unit Konversi Pengeluaran Perkapita Jawa Timur 2015-2019

\begin{tabular}{crrrrr}
\hline Variabel/ & \multicolumn{5}{c}{ Tahun } \\
\cline { 2 - 6 } Statistik & \multicolumn{1}{c}{2015} & 2016 & \multicolumn{1}{c}{2017} & 2018 \\
Obs & 29.209 & 29.477 & 29.887 & 29.780 & 30.021 \\
Weight & 38.813 .758 & 39.018 .230 & 39.238 .500 & 39.448 .872 & 39.649 .219 \\
Pengeluaran_Perkapita (k) & & & & \\
Mean & 830.473 & 870.412 & 938.801 & 1.006 .078 & 1.036 .177 \\
Std. Dev. & 950.210 & 847.399 & 937.240 & 960.021 & 1.149 .345 \\
Min & 98.469 & 150.065 & 111.664 & 134.292 & 147.837 \\
Max & 35.600 .000 & 27.800 .000 & 25.000 .000 & 62.100 .000 & 80.900 .000 \\
CV & 114,42 & 97,36 & 99,83 & 95,42 & 110,92 \\
Max/Min & 361,53 & 185,25 & 223,89 & 462,43 & 547,22 \\
Konversi_Pengeluarany $(\boldsymbol{u})$ & & & & \\
Mean & 2,65 & 2,63 & 2,71 & 2,73 & 2,67 \\
Std. Dev. & 2,79 & 2,32 & 2,44 & 2,36 & 2,48 \\
Min & 0,31 & 0,47 & 0,34 & 0,39 & 0,38 \\
Max & 92,21 & 70,41 & 71,36 & 117,10 & 142,57 \\
CV & 105,37 & 88,40 & 90,20 & 86,45 & 93,10 \\
Max/Min & 298,83 & 149,72 & 209,23 & 298,82 & 378,26 \\
\hline
\end{tabular}

Sumber : Survei Sosial Ekonomi Nasional (Susenas) Jawa Timur, Maret 2015-2019. Diolah menggunakan Stata 12. Nilai CV dan Max/Min Diolah Penulis.

Untuk besaran garis kemiskinan tiap kabupaten/kota di Jawa Timur (lihat Tabel 2), selama 2015-2019 untuk semua indikator; mean, standar deviasi, nilai minimum, nilai maksimum, coefficient of variation, dan perbandingan nilai maksimum terhadap minimum mengalami peningkatan setiap tahunnya. Bahkan untuk perbandingan besaran garis kemiskinan terendah dan tertinggi mencapai dua kali lipatnya di tahun 2019. Dari nilai coefficient of variation dapat dilihat 
bahwa variasi garis kemiskinan terhadap rata-rata garis kemiskinan kabupaten/kota di Jawa Timur juga semakin besar.

Tabel 2. Statistik Deskriptif Garis Kemiskinan Kabupaten/Kota di Jawa Timur 2015-2019

\begin{tabular}{crrrrr}
\hline \multirow{2}{*}{ Statistik } & \multicolumn{7}{c}{ Tahun } \\
\cline { 2 - 6 } Obs & \multicolumn{1}{c}{2015} & 38 & 2017 & 2018 & \multicolumn{1}{c}{2019} \\
Mean & 38 & $325.997,76$ & $341.453,55$ & $367.026,47$ & $387.058,21$ \\
Std. Dev. & $309.858,26$ & $52.389,31$ & $57.983,36$ & $67.592,34$ & $73.622,23$ \\
Min & $51.019,28$ & 239.339 & 250.942 & 268.592 & 283.321 \\
Max & 228.573 & 438.283 & 474.365 & 530.178 & 567.474 \\
CV & 418.930 & 16,07 & 16,98 & 18,42 & 19,02 \\
Max/Min & 16,47 & 1,83 & 1,89 & 1,97 & 2,00 \\
\hline Sumber : Data dan Informasi Kemiskinan Kabupaten/Kota, 2015-2019. Diolah. & \multicolumn{5}{c}{}
\end{tabular}

Secara empiris dengan menggunakan data pengeluaran individu Susenas Maret Jawa Timur 2015-2019 (lihat Tabel 3), diperoleh hasil terjadi penurunan nilai indeks gini rupiah pengeluaran perkapita setiap tahunnya. Ini menunjukkan terjadi penurunan tingkat ketimpangan atau kesenjangan pengeluaran individu dalam rumah tangga di Jawa Timur. Demikian juga untuk nilai indeks gini hasil konversi pengeluaran perkapita ke dalam unit paket kebutuhan dasar, selama tahun 2015-2019, mengalami penurunan. Ini berarti tingkat kemampuan membelanjakan pengeluaran setiap individu dalam unit paket kebutuhan dasar, relatif menurun kesenjangannya.

Tabel 3. Hasil Indeks Gini Pengeluaran Perkapita dan Unit Konversi Pengeluaran Perkapita Jawa Timur 2015-2019

\begin{tabular}{cccccc}
\hline Keterangan & \multicolumn{5}{c}{ Tahun } \\
\cline { 2 - 5 } & 2015 & 2016 & 2017 & 2018 & 2019 \\
\hline $\begin{array}{c}\text { Indeks Gini } \\
\begin{array}{c}\text { Pengeluaran_- } \\
\text { Perkapita (k) }\end{array}\end{array}$ & 0,41537 & 0,40195 & 0,39630 & 0,37930 & 0,36981 \\
\hline $\begin{array}{c}\text { Indeks Gini } \\
\text { Konversi_Pen } \\
\text { geluaran (u) }\end{array}$ & 0,39050 & 0,37536 & 0,36845 & 0,35347 & 0,34261 \\
\hline $\begin{array}{c}\text { Koefisien Bias } \\
\text { Gini (KBG) }\end{array}$ & 0,06369 & 0,07084 & 0,07559 & 0,07308 & 0,07939 \\
\hline
\end{tabular}

Sumber : Survei Sosial Ekonomi Nasional (Susenas) Jawa Timur, Maret 2015-2019. Garis Kemiskinan Kabupaten/Kota 2015-2019. Indeks Gini diolah dari data individu menggunakan Stata 12. KBG Diolah.

Potret kesenjangan yang diperoleh dari data pengeluaran perkapita, untuk tahun 2015-2019 di Jawa Timur, salah satunya sebagai dampak kompensasi variasi harga antar wilayah kabupaten/kota di Jawa Timur. Karena secara riil ketimpangan kesejahteraan di Jawa Timur selama 2015-2019, justru lebih rendah (lihat Gambar 3). Ini juga tercermin dari nilai $K B G$ yang positif. Satu hal yang menjadi catatan dari hasil $K B G$ ini, selama periode 2015-2019 di Jawa Timur, terjadi peningkatan nilai besaran dari $K B G$, untuk setiap tahunnya. Hal ini menunjukkan bahwa variasi harga terutama komoditi kelompok kebutuhan dasar, masih relatif bervariasi antar wilayah. Sehingga nilai ketimpangan dari pengeluaran perkapita semakin berjarak dari nilai ketimpangan kesejahteraan yang riil untuk Jawa Timur selama 2015-2019. Tentu hasil ini akan memberi informasi ketimpangan kesejahteraan yang bias dari indeks gini, jika hanya berdasarkan data pengeluaran perkapita apa adanya.

\section{KESIMPULAN}


Berdasarkan kajian ini maka perlu kehati-hatian dalam menafsirkan hasil indeks gini dari data pengeluaran (konsumsi), terutama jika digunakan untuk melihat ketimpangan kesejahteraan masyarakat. Hasil kajian baik teoritis maupun empiris menunjukkan bahwa ada faktor deviasi harga sebagai akibat penggunaan data konsumsi. Dengan menggunakan konversi terlebih dahulu dengan nilai garis kemiskinan sebagai representasi unit konversi paket kebutuhan dasar, maka data pengeluaran akan lebih riil mencerminkan tingkat kemampuan daya beli masyarakat. Sehingga akan memberi hasil indeks gini yang lebih riil, mencerminkan ketimpangan kesejahteraan masyarakat. Koefisien bias gini yang dihasilkan dalam kajian ini dapat digunakan untuk melihat anomali yang terjadi dalam penghitungan gini dengan dua data diatas.
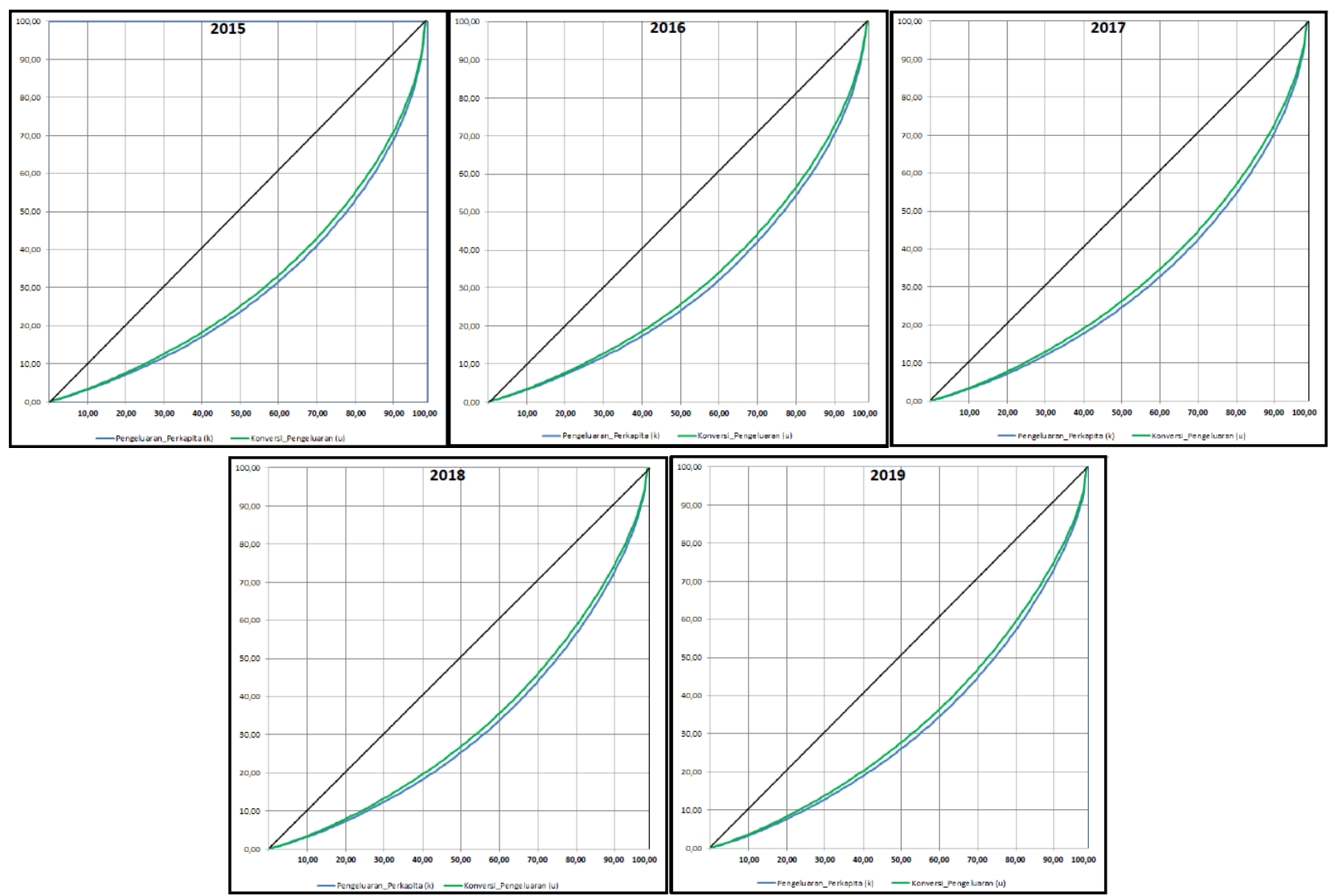

Gambar 3. Kurva Lorenz Pengeluaran Perkapita ( $k=$ Warna Biru) dan Konversi Pengeluaran Perkapita ( $u=$ Warna Hijau) Jawa Timur 2015-2019.

\section{UCAPAN TERIMA KASIH}

Syukur Alhamdulillah kami panjatkan kehadirat Allah Subhanahu wa ta'ala atas karunia-Nya kami senantiasa diberikan rahmat dan masih dalam hidayah-Nya. Karya tulis ini wujud terima kasih kami terutama atas bimbingan Bapak Gantjang Amannullah (Direktur Statistik Kesejahteraan Rakyat), dimana ide tulisan ini pernah kami diskusikan saat Beliau masih bertugas di Jawa Timur. Terima kasih juga kami sampaikan kepada Bapak Dadang Hardiwan (Kepala BPS Provinsi Jawa Timur) yang selalu memotivasi Statistikawan di Jawa Timur untuk berkarya mengembangkan kreatifitas keilmuan kami, di tengah aktifitas kedinasan. Tak lupa ucapan terima kasih kepada Bapak Kepala Bagian dan Bidang di BPS Provinsi Jawa Timur serta kolega kami di BPS Provinsi Jawa Timur serta keluarga kami tercinta.

\section{DAFTAR PUSTAKA}

Abbott, Brant dan Brace, Robin. (2020). Has Consumption Inequality Mirrored Wealth Inequality in the Survey of Consumer Finances? Economics Letters 193 (2020) 109289.

Badan Pusat Statistik. (2018). Penghitungan dan Analisis Kemiskinan Makro Indonesia Tahun 2018. BPS. Jakarta. 
Badan Pusat Statistik dan World Bank Institute. (2002). Dasar-Dasar Analisis Kemiskinan. BPS-World Bank Institute. Jakarta.

Badan Pusat Statistik. (2005). Analisis dan Penghitungan Tingkat Kemiskinan 2005 Dari Data Susenas Tahun 2005. BPS. Jakarta.

Badan Pusat Statistik. (2016). Data dan Informasi Kemiskinan Kabupaten/Kota 2015. BPS. Jakarta.

Badan Pusat Statistik. (2017). Data dan Informasi Kemiskinan Kabupaten/Kota 2016. BPS. Jakarta.

Badan Pusat Statistik. (2018). Data dan Informasi Kemiskinan Kabupaten/Kota 2017. BPS. Jakarta.

Badan Pusat Statistik. (2018). Data dan Informasi Kemiskinan Kabupaten/Kota 2019. BPS. Jakarta.

Badan Pusat Statistik. (2019). Data dan Informasi Kemiskinan Kabupaten/Kota 2019. BPS. Jakarta.

Gupta, Somesh Das. (2007). Gini Association and Pseudo Lorenz Curve. Communications in Statistics-Theory and Methods, 28:9, 2181-2199.

ILO. (2003). Household income and expenditure statistics-Report II, Seventeenth International Conference of Labour Statisticians. Geneva.

Lambert, Peter J. dan Aronson, J. Richard. (1993). Inequality Decomposition Analysis and the Gini Coefficient Revisited. The Economic Journal, Vol. 103, No. 420. 1221-122.

Kuncoro, Mudrajad. (2010). Masalah, Kebijakan, dan Politik Ekonomika Pembangunan. Penerbit Erlangga. Jakarta.

Kuncoro, Mudrajad. (2013). Mudah Memahami dan Menganalisis Indikator Ekonomi. UPP STIM YKPN. Yogyakarta.

Zheng, Z., Tapas, M., dan Yang, Y. (2020). Inflation and Income Inequality in a Variety-Expansion Growth Model with Menu Costs. Economics Letters 194 (2020) 109373.

Ray, Debraj. (1998). Development Economics. Princeton University Press, Princeton. New Jersey.

RI (Republik Indonesia). (2015). Peraturan Presiden No. 2 Tahun 2015 tentang Rencana Pembangunan Jangka Menengah Nasional Tahun 2015-2019. Lembaran Negara RI Tahun 2015, No. 164. Sekretariat Negara. Jakarta.

RI (Republik Indonesia). (2020). Peraturan Presiden No. 18 Tahun 2020 tentang Rencana Pembangunan Jangka Menengah Nasional Tahun 2020-2024. Lembaran Negara RI Tahun 2020, No. 66. Sekretariat Negara. Jakarta.

United Nations Conference on the Standardization of Geographical Names. (2017). Identification of Islands and Standardization of Their Names. New York, 8 -17 August 2017. https://unstats.un.org/unsd/geoinfo/ungegn/docs/ 11th-uncsgn-docs/E Conf.105 115 CRP.115 Agenda\%209a\%20Identification\%20of\%20Islands\%20and\%20Stan dardization\%20of\%20Their\%20Names BIG Indonesia.pdf 